\title{
DEVELOPMENT OF A DUAL PCR METHOD FOR DETECTION OF PASTEURELLA MULTOCIDA AND HAEMOPHILUS PARASUIS
}

\author{
Zhang Yu \\ Veterinary Medicine Student of the Joint Master's Degree Program \\ Henan Institute of Science and Technology of China and Sumy National Agrarian University of Ukraine \\ ORCID: 0000-0002-4848-8063 \\ 3131438211@qq.com \\ Rebenko Halyna \\ $\mathrm{PhD}$ in Veterinary Sciences, Associated Professor \\ Sumy National Agrarian University (Sumy, Ukraine) \\ ORCID: 0000-0002-1884-4901 \\ rebenko.halina@gmail.com \\ Hu Jianhe \\ Professor \\ Henan Institute of Science and Technology (Henan, China) \\ ORCID: 0000-0002-6768-0851 \\ xxilanhe@126.com \\ Zhang Shouping \\ $\mathrm{PhD}$ \\ Henan Institute of Science and Technology (Henan, China) \\ ORCID: 0000-0003-1774-1924
}

Pasteurella multocida and Haemophilus parasuis are the main pathogens of porcine respiratory disease syndrome, and often are the common pathogens of porcine pulmonary disease in collectivized pig farms. It has brought great influence on the pig industry and seriously hampered the healthy development of pigs. Therefore, the rapid detection method for Pasteurella multocida and Haemophilus parasuis is the key to its successful prevention and control. In the process of diagnosis, we need to conduct laboratory tests for confirming of preliminary diagnosis, that can be made based on the history, clinical symptoms, pathological changes of necropsy and epidemiological characteristics of the disease. Traditional diagnostic techniques, such as bacterial isolation and immunological test, are time-consuming and laborious, and are not suitable for rapid clinical diagnosis, nor for large-scale epidemiological investigation. Therefore, it is necessary to establish an accurate and rapid method to identify the two common respiratory pathogens in pigs.

In this paper, Pasteurella multocida and Haemophilus parasuis were used as research objects to establish a dual PCR detection method. The main research contents are as follows: A dual PCR assay was established to detect Pasteurella multocida and Haemophilus parasuis simultaneously. By using Pasteurella multocida and Haemophilus parasuis specific primers, and adjusting primer concentration and annealing temperature, a dual PCR method for detecting Pasteurella multocida and Haemophilus parasuis was established.

The rapid detection method for Pasteurella multocida and Haemophilus parasuis established in this study has high specificity and sensitivity, and can realize rapid and accurate identification of pathogenic bacteria in a relatively short period of time, providing a new technical means for rapid detection in clinical and grassroots laboratories.

Keywords: Pasteurella multocida; Haemophilus parasuis; Double PCR; Detection

DOI: https://doi.org/10.32845/bsnau.vet.2021.1.2

Introduction

Pasteurella multocida disease is an infectious disease caused by Pasteurella bacteria, which can be transmitted between the same or different animals. In the past, it has been called Pasteurella multocida by the names of the animals that infect it, horse, cow, sheep, poultry, rabbit, and later collectively. Acute manifestations in animals are characterized by septicemia and hemorrhagic inflammation of tissues and organs, also known as hemorrhagic septicemia. (Starkey, S.R. \& Donnelly, T.M., 2012). Chronic type is often manifested as suppurative lesions in various organs, which are often mixed with other pathogens or secondary infections. The disease is widespread in countries around the world, with tropical and subtropical countries most affected. Swine pasteurellosis, also known as pulmonary disease of Swine, commonly known as "laryngitis" or "distemper of the neck", is an important infectious disease caused by Pasteurella multocida (PM), which often resided in the upper respiratory tract

of pigs. The disease is mainly caused by temperature disorders, decreased resistance, poor growth environment and extreme weather. Severe pig sitting position mouth breathing, causing pneumonia, dyspnea.

Haemophilosis, also known as Glesser's disease, is caused by Haemophilus parasuis (HPS) or Glaesserella parasuis (Lin, Wei-Hao, Shih, Hsing-Chun, Lin, Chuen-Fu, Yang, ChengYao, Lin, Chao-Nan \& Chiou, Ming-Tang., 2019).

It is a kind of symbiotic bacteria in the upper respiratory tract of pigs, which invades the body when the resistance of pigs is low (Li J Y, Zhang J M, Xu C G, et al. ,2010; Si Z S, Wang G Y. 2011; Rebenko, H. (2014), Ni, Hong-Bo, Gong, Qing-Long, Zhao, Quan, Li, Xiao-Yue, Zhang, Xiao-Xuan. (2020). It often causes serous or fibrinous multiple serositis, arthritis, meningitis, high fever, respiratory disorders and other symptoms in pigs, which can lead to death in severe cases. At present, in Pasteur bacteria 
genera, deputy haemophilus taxonomic position remain uncertain, it is because it with other haemophilus species lack of nucleic acid homology between vice pigs and haemophilus strain between the presence of large amounts of heterologous gene, researchers put forward, in vice pig haemophilus has confirmed there is more than one category of bacteria (Ma, Lina, Wang, Liyan, Chu, Yuefeng, Li, Xuerui, Cui, Yujun, Chen, Shengli, Zhou, Jianhua, Li, Chunling, Lu, Zhongxin, Liu, Jixing \& Liu, Yongsheng., 2016). HPS requires special conditions to enter the animal body and lead to the outbreak of systemic disease. Normally, the pathogen can cause Glaser's disease, which is characterized by meningitis, arthritis and multiple serositis. Both bacteria can cause fever, dyspnea, cough, swelling of the joints, and similar pathological changes such as bleeding and cellulose exudate in the lungs of pigs. Although the disease can occur in any season of the year, the incidence is higher in spring, fall and winter than in summer. Once clinical symptoms appear, high dose antibiotics should be applied in time for treatment, and prophylactic drugs should be given to the whole group of pigs. According to the local epidemic situation, the pig farm should do a good job of immune prevention, strengthen feeding management and reduce stress response (Nedbalcova, Katerina, Satran, P., Jaglic, Zoran, Ondriasova, R. \& Kucerova, Z.,2018).

$\mathrm{Pm}$ should pay attention to the disease difference with swine erysipelas, swine fever, swine flu, these belong to infectious diseases, and can make sick pigs high temperature rising to a certain extent, waste and loss of appetite, and the symptom such as bleeding, but ensure that swine flu will only lead to the pig infection occurs, the other animals not infection occurs, and the disease is seasonal, generally has the very high incidence in winter, but the mortality rate is low; Swine fever is usually also a pig with susceptibility, and the prevalence of a wide range, but will not lead to salivation, throat swelling, the body will not be sitting or lying dog posture; Swine erysipelas can cause septic disease, and only cannot lie down, the throat will not swell, and will not be a dog sitting or lying posture. Through the above differences to identify, timely and effective symptomatic treatment, to ensure the cure rate. HPS attention and streptococcal disease, infectious pleural pneumonia differential diagnosis. Arthritis, hocks, swelling of wrist joints, severe pain, limp leg caused by Haemophilus parasuis, a pinch with the hand, pain scream; There was a serous fibrin exudate in the articular cavity. Pericardial effusion, serous fibrinous pleurisy, and pericarditis. The surface of the lung is covered with a pale yellow serous fibrous membrane. On section, there are focal dark red congested areas. Streptococcal arthritis caused by swelling joints, early hard, temperature rise, later soft, touch the feeling of fluctuation, acupuncture flow pus; A few hardened and thickened skin; At necropsy, synovial fluid is turbid, with yellowish-white cheesy mass, subcutaneous colloid edema around the joints, and suppurative necrosis foci, and necrosis of articular cartilage in severe cases. The disease is easily confused with infectious pleural pneumonia, but most of the lesions caused by this disease are meningitis, arthritis and claudication, while infectious pleural pneumonia is less common. Diagnostic disease is confirmed by clinical examination, necropsy, and laboratory examination. In this study, a double-layer PCR method for detecting PM and HPS was established based on laboratory detection to realize rapid and efficient diagnosis.

\section{Literature Review}

In recent years, these two diseases have caused great economic losses to the pig industry (Zhang Bin, Tang Chen, Liao Ming, et al., 2014, Cardoso-Toset F, Gómez-Laguna J, Callejo M, et al., 2013). Although there are conventional PCR methods for the detection of these two diseases, there are problems such as cumbersome operation and long time consuming in practical application. Therefore, an efficient, rapid and accurate detection method can save more time for subsequent treatment and prevention and control, and minimize economic losses to the greatest extent (Liang Q, Yang B, Yong S L, et al., 2018, Zhang Y, Li J, Li W J, et al., 2017).

Multiple PCR technology is a method of simultaneously amplifying multiple nucleic acid fragments by adding two or more pairs of primers in the same PCR amplification system. A single multiple PCR can identify and detect pathogens at the same time. It has unique advantages and high practical value in the differential diagnosis of clinical mixed infections Moriy, Nagamine K, Tomita N, et al, 2010; Malorny B, Tassios P T, Radstrom P , et al, 2003). In this experiment, a dual PCR method was established for the identification of Pasteurella polycida and Haemophilus parasuis from swine samples at one time. Compared with the traditional bacteriological detection method, it was simple, rapid and accurate.

\section{Materials}

\subsection{All strains}

Escherichia coli, Actinobacillus pleuropneumoniae, Streptococcus pneumoniae, Staphylococcus aureus, Pasteurella multocida was presented by Ms. Wang Lirong. Haemophilus parasuis was donated by Mr. Ding Ke of Henan University of Science and Technology.

\subsection{Main reagents and instruments}

Nicotinamide adenine dinucleotide (NAD) and DL-2000 Marker, both purchased from Sangon Bioengineering (Shanghai) Co, Ltd.; Trypsin soybean agar (TSA) and Trypsin soybean broth (TSB) medium were purchased from Oxoid Company in the United States. Bacterial DNA extraction kit, TaqDNA polymerase, Proteinase K, Primer Star DNA polymerase, gel recovery kit, plasmid extraction kit, pMD-19 plasmid and gel recovery kit were all purchased from Takara Biological Company.

\section{Methods}

\subsection{Medium preparation}

TSA solid medium: $40 \mathrm{~g}$ trypan Soy Agar (TSA) was accurately weighed, $940 \mathrm{~mL}$ purified water was added, fully shaken, heated to dissolve, autoclave sterilization at $121^{\circ} \mathrm{C}$ for $15 \mathrm{~min}$, and $50 \mathrm{~mL}$ filtered and sterilized veal serum and $10 \mathrm{~mL}$ $0.01 \%$ NAD were added.

TSB liquid culture medium: accurately weigh $30 \mathrm{~g}$ trypan Soy Broth (TSB), add $940 \mathrm{~mL}$ of purified water, shake well and autoclave at $121^{\circ} \mathrm{C}$ for $15 \mathrm{~min}$, add $50 \mathrm{~mL}$ of filtered and sterilized calf serum and $10 \mathrm{~mL}$ of $0.01 \% \mathrm{NAD}$.

Blood agar plate: $30 \mathrm{~g}$ of nutrient agar was accurately weighed and dissolved in $890 \mathrm{~mL}$ of purified water. After fully shaken, it was autoclaved at $121.0^{\circ} \mathrm{C}$ for $15 \mathrm{~min}$, cooled to about $45^{\circ} \mathrm{C}$, and $100 \mathrm{~mL}$ of fresh anticoagulant sheep blood and $0.01 \% \mathrm{NAD} 10 \mathrm{~mL}$ of cross sterilization rate were added. After fully shaken, it was poured into plate.

$0.01 \%$ nicotinamide adenine dinucleotide (NAD): accurately weighed $5 \mathrm{mg} \mathrm{NAD}$, dissolved in $50 \mathrm{~mL}$ pure water, filtered and sterilized.

\subsection{Bacterial culture}

Pasteurella multocida was activated on TSA solid medium at $37^{\circ} \mathrm{C}$, then transferred to TSB liquid medium, cultured at $37^{\circ} \mathrm{C}$ for $18 \mathrm{~h}$, and stored at $4{ }^{\circ} \mathrm{C}$ for later use.

The culture of Haemophilus parasuis is more difficult than that of Pasteurelli, so it needs to be activated on blood AGAR plate, then transferred to TSB liquid medium for culture at $37^{\circ} \mathrm{C}$ 
for $24 \mathrm{~h}$, and stored at $4{ }^{\circ} \mathrm{C}$ for later use.

2.3 Primer design and synthesis

According to the gene sequences registered in GenBank,
Primer 5 software was used to design specific primers for the conserved regions of these three pathogens, and the modified primers were synthesized in Sangon Bioengineering (Shanghai) Co., Ltd.

Sequences of primers

\begin{tabular}{|c|l|l|c|}
\hline Name & \multicolumn{1}{|c|}{ Sequence(5'-3') } & Amplicon size/bp \\
\hline Pasteurella multocida & $\mathrm{F}^{\prime}$ & AGATCCTGGCTCAGATTGAACG & 485 \\
\cline { 2 - 4 } & $\mathrm{R}^{\prime}$ & CTCTGTAATTAACGTCAATGATGCC & 339 \\
\hline Haemophilus parasuis & $\mathrm{F}^{\prime}$ & AAAATGGGCGAATGGTG & \\
\cline { 2 - 4 } & $\mathrm{R}^{\prime}$ & TGCGTGTCCTGGTGTATCTAA & \\
\hline
\end{tabular}

\subsection{Extraction of bacterial DNA}

The TAKARA bacterial DNA extraction kit was used for the operation. See Annex A for the steps.

\subsection{Determination of DNA content}

After preheating for $30 \mathrm{~min}$, the ultrafine rapid nucleic acid protein analyzer UV-1800 was used to proofread the spectrum, adjust the wavelength to $750 \mathrm{~nm}$, correct the baseline, rinse the colorimetric dish with ultrapure water, add $50 \mu \mathrm{LTE}$ buffer as blank control, and the rest were samples to be tested (sample was diluted with TE buffer 50 times), read the absorbance value, and calculate the DNA content by the formula. DNA content = $(1.45 \times 0 D 280) /(0.78 \times 0 D 260)$. When the calculated value is greater than 1.9, it indicates that there is RNA contamination in the sample to be tested. When the calculated value is less than 1.6 , it indicates that there is protein and phenol contamination in the sample to be tested.

2.6 Optimization of dual PCR amplification conditions

Gradient PCR apparatus was used for amplification. In order to screen the optimal PCR amplification conditions, genomic DNA of PM and HPS was used as the template for PCR, and six $\mathrm{PCR}$ annealing temperatures were set in the experiment, which were $53^{\circ} \mathrm{C}, 54^{\circ} \mathrm{C}, 55^{\circ} \mathrm{C}, 56^{\circ} \mathrm{C}, 57^{\circ} \mathrm{C}$ and $58^{\circ} \mathrm{C}$, respectively. PCR reaction system: $20 \mu \mathrm{L}$ system, DNA Taq enzyme $10 \mu \mathrm{L}$, upper and lower primers $0.5 \mu \mathrm{L}$ each, DNA template $2 \mu \mathrm{L}$, DEPC water $7 \mu \mathrm{L}$; The PCR reaction conditions were as follows: pre-denaturation at $95^{\circ} \mathrm{C}$ for $5 \mathrm{~min}$, denaturation at $95^{\circ} \mathrm{C}$ for $30 \mathrm{~s}$, annealing at $53-58^{\circ} \mathrm{C}$ for $30 \mathrm{~s}$, extension at $72^{\circ} \mathrm{C}$ for $60 \mathrm{~s}$, a total of 30 cycles. Finally, it was extended at $72.0^{\circ} \mathrm{C}$ for $10 \mathrm{~min}$ and stored at $4^{\circ} \mathrm{C}$. The reaction products were detected by $1.5 \%$ AGAR gel electrophoresis. The annealing temperature of double PCR was optimized.

\subsection{Specificity Verification}

In order to further verify the test set up double PCR specificity, on purpose strain and E. coli, Actinobacillus pleuropneumonia, Streptococcus pneumoniae, Staphylococcus aureus DNA as a template, while adding several kinds of primers, using the optimized dual PCR reaction conditions for PCR amplification, reaction products with 1.5\% AGAR gel electrophoresis detection.

\section{Results and analysis}

\subsection{Optimization results of reaction conditions}

The reaction system in the EP tube was centrifugally mixed, and the reaction amplification was carried out using PCR instrument. After verification at different annealing temperatures, the setting procedure with the highest efficiency was: $95^{\circ} \mathrm{C}$ predenaturation for $5 \mathrm{~min}, 95^{\circ} \mathrm{C}$ denaturation for $30 \mathrm{~s}, 55^{\circ} \mathrm{C}$ annealing for $30 \mathrm{~s}, 72^{\circ} \mathrm{C}$ extension for $60 \mathrm{~s}$, a total of 30 cycles.

3.2 Double PCR electrophoresis results of Pasteurella multocida and Haemophilus parasuis

In Figure 1, the electrophoresis results of primer No. 1 and primer No. 2 showed clear bands with maximum brightness, and the molecular weight of DNA was $485 \mathrm{bp}$, indicating that primer No. 1 and primer No. 2 were the best primers for Pasteuella multocida, with the best amplification effect. Therefore, primer No. 1 and primer No. 2 were selected for Pasteuella multocida porcine (both primer No. 1 and primer No. 2 were the same primer). The PCR annealing temperature was $55.0^{\circ} \mathrm{C}$. The electrophoresis results of primers No. 3 and No. 4 are shown in the figure. The molecular weight of DNA is $339 \mathrm{bp}$, indicating that the best primers for Haemophilus parasuis are No. 3 and No. 4, which have the best amplification effect. The PCR annealing temperature was $55^{\circ} \mathrm{C}$.

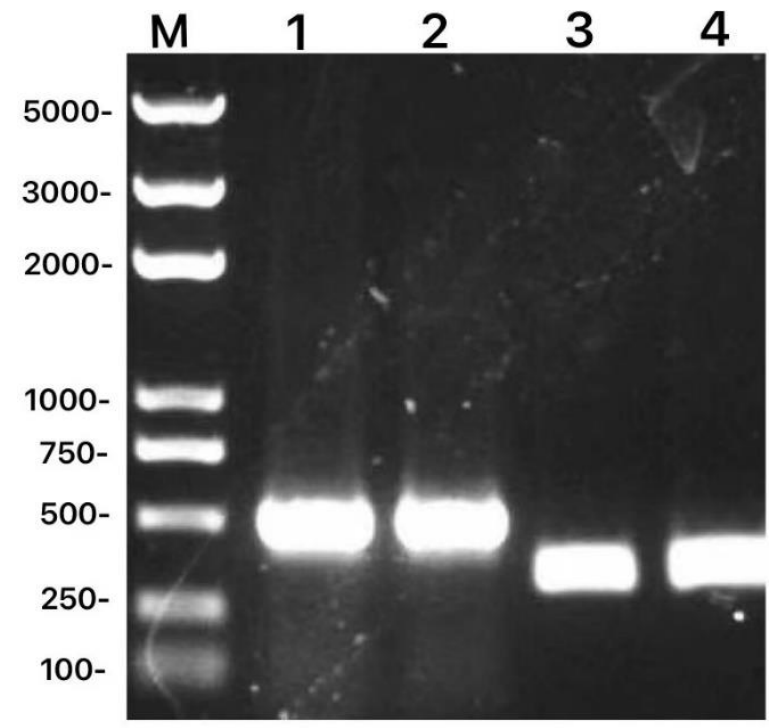

Fig. 1

Double PCR electrophoresis results of Pasteurella multocida and Haemophilus parasuis M: DL5000 DNA Marker ; 1-2: Pm; 3-4: Hps 


\subsection{Specificity Verification}

The results are shown in Figure 2 and Figure 3.

Double PCR method for Pasteuella multocida, Haemophilus parasuis, Escherichia coli, Actinobacillus pleuropneumonia, Streptococcus pneumoniae, Staphylococcus aureus genome DNA test results (see figure 2,3 ) show that for Pasteuella multocida inspection only $2485 \mathrm{bp}$, the specific purpose of strip for the detection of Haemophilus parasuis appears only four $339 \mathrm{bp}$ band specific purpose, for other negative control without amplification bands in the genomic DNA tests. (The experiments in Figure 2 and Figure 3 were performed on the same glue for electrophoresis) The non-target bacteria did not amplify the target band, and the DNA amplification results of the target bacteria at 485bp and $339 \mathrm{bp}$ were good, indicating the high specificity of the method for detection of the target bacteria.

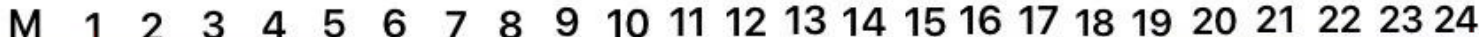

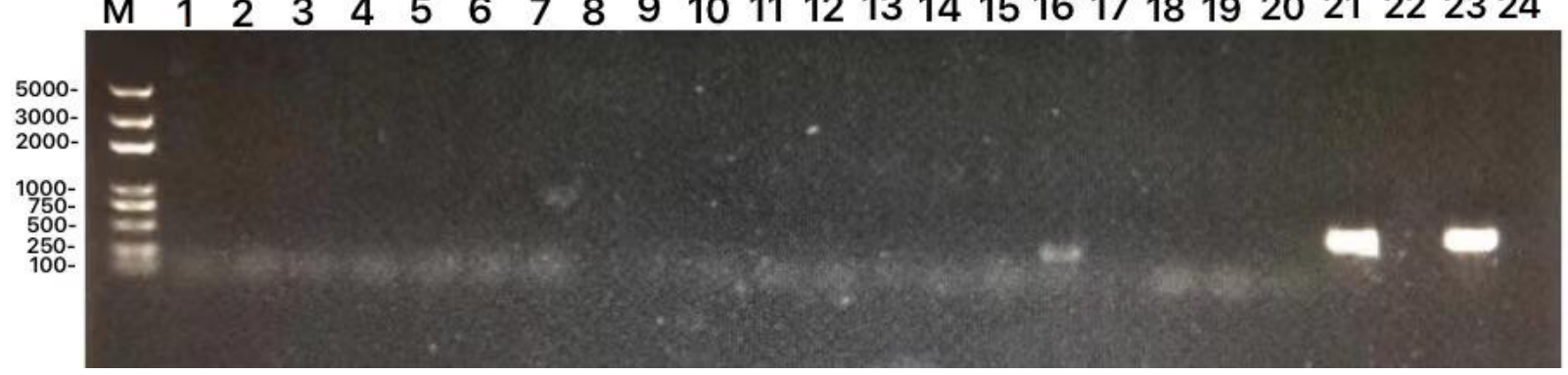

Fig. 2

From No.1 to No.24 PCR specific detection products

M: DL5000 DNA Marker ; 1-5:Escherichia coli;

6-10: Actinobacilus pleuropneumoniae; 11-15: Streptococcus pneumoniae;

16-20:Staphylococcus aureus; 21,23: Pasteuella multocida; 22,24:blank control

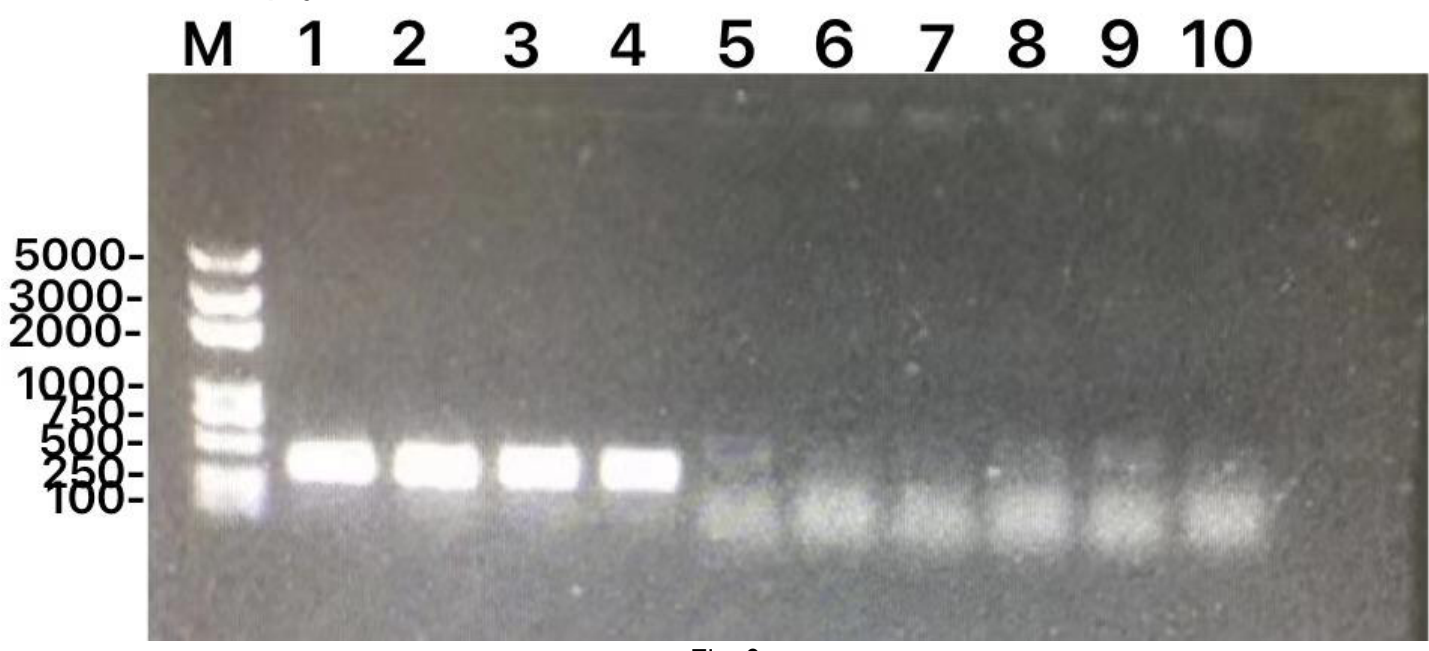

Fig. 3

From No.1 to No.10 PCR specific detection products

M: DL5000 DNA Marker; 1-4: Haemophilus parasuis; 5: Escherichia coli;

6: Actinobacillus pleuropneumoniae; 7: Streptococcus pneumoniae; 8: Staphylococcus aureus; 9-10: blank control

\subsection{Summary}

Pasteurella and Haemophilus double PCR reaction, the best annealing temperature is $55.0^{\circ} \mathrm{C}$, the specificity of the two pairs of primers is stronger, no cross reaction for the purpose strain amplification. Vice pig kill PAP bacteria and Haemophilus specific product size in the order of $485 \mathrm{bp}$ and $339 \mathrm{bp}$, after agarose electrophoresis can clearly distinguish, nothing specific amplification interference experiment, can detect two kinds of pathogenic bacteria in the same $\mathrm{PCR}$ reaction.

Therefore, the dual PCR detection method for Pasteurella multocida and Haemophilus parasuis established in this study has many advantages. First, one method can be used to distinguish the two pathogens. Second, this method has strong specificity, low cost and high amplification efficiency. Thirdly, this method is suitable for laboratory detection and diagnosis.

\section{Discussing}

In recent years, Haemophilus parasuis has become one of the typical bacterial diseases that cause the death of nursery pigs under the conditions of large-scale breeding (Gao PC, Chu YF, Zhao P, et al, 2008; Xue G C, Ren T., 2009). Porcine pulmonary disease caused by Pasteurella multocida infection is also a common infectious disease that causes the death of pigs. These two bacterial diseases occur all over the world, and both can cause respiratory symptoms of pigs (Harper M, Boyce J D., 2017; Li J, Xie Y Z, Xuan Xiongbiao, et al., 2011). Due to the use of a large number of antibiotics in pig farms after the disease, it is difficult to isolate and cultivate the bacteria, and the accuracy of isolation and identification is low. In addition, some bacteria have strict requirements on the growth conditions and slow growth, which not only brings challenges to the diagnosis of the disease, but also causes significant economic losses to the pig industry.

Laboratory tests in recent years, In the clinical samples tested, the detection rate of Haemophilus parasuis and Pasteurella multocida was relatively high, and the proportion of $\mathrm{Hae}$ mophilus parasuis and Pasteurella multocida was relatively large. Moreover, it was difficult to isolate and cultivate the two kinds of 
bacteria. Therefore, in order to improve the efficiency and accuracy of detection, this study combined molecular biology methods and established a dual PCR method for simultaneous detection of the two kinds of bacteria on the basis of the existing detection methods. In the establishment of optimal PCR amplification. In the process of the system, the main principle is to make changes in the basic amplification system, and select the optimal reaction conditions through the light and shade of the electrophoresis map and the width of the bands, among which the main factors are annealing temperature, DNA proportion and primer proportion. The optimum annealing temperature was studied only in this experiment.

Zhang Yuan, Wei Caiwen, Li Jian, et al. (2014). improved the method of capsular clustering of Pasteurella multocida by establishing multiplex PCR, indicating that there are many types of Pasteurella multocida infection, which are mixed with Streptococcus suis, Haemophilus parasuis, Actinomycetes pleuritis and other infections. Therefore, it is necessary to establish a PCR method that can detect multiple pathogens simultaneously. Miao Lizhong et al. designed specific primers according to the HPS INFB gene sequence in GenBank, and constructed a real-time fluorescence quantitative PCR method for rapid detection of HPS
(Cai X W., 2006).

The dual PCR method established in this study could successfully ampliate Pasteurella multocida and Haemophilus parasuis with amplification lengths of $485 \mathrm{bp}$ and $339 \mathrm{bp}$, respectively, without cross-reaction with other related pathogens. This method can be used to distinguish two kinds of pathogens, and this method has strong specificity, low cost, high amplification efficiency, and is suitable for rapid laboratory detection.

\section{CONCLUSIONS}

This study established a dual PCR detection method that can simultaneously detect Pasteurella multocida and Haemophilus parasuis. By using Pasteurella multocida and Haemophilus parasuis specific primers, by adjusting the primer concentration, annealing temperature and other conditions, a dual PCR detection method for Pasteurella multocida and Haemophilus parasuis was established. This research is mainly aimed at the rapid detection method established for Pasteurella multocida and Haemophilus parasuis, which has high specificity and sensitivity, and realizes the rapid and accurate identification of pathogenic bacteria in a short time. This clinical and basic laboratory rapid detection for Pasteurella multocida and Haemophilus parasuis provides a new technical means.

\section{References:}

1. Cai X W. (2006). Isolation and characterization of Haemophilus parasuis and development of its diagnostic method and inactivated bacterin [D]. Wuhan: Huazhong Agricultural University,

2. Cardoso-Toset F, Gómez-Laguna J, Callejo M, et al. (2013). Septicaemic pasteurellosis in free-range pigs associated with an unusual biovar 13 of Pasteurella multocida. Vet Microbioogyl, 167(3-4): 690-694.

3. Gao PC, Chu YF, Zhao P, et al. (2008). Screening of culture conditions for Haemophilus parasuis and its pathogenicity test to guinea pigs. Advances in Veterinary Medicine, (10):10-13.

4. Harper M, Boyce J D. (2017). The Myriad Properties of Pasteurella multocida Lipopolysaccharide. Toxins, 21, 9(8): 254275.

5. Li J Y, Zhang J M, Xu C G, et al. (2010). Research progress on main virulence factors and pathogenic mechanism of Haemophilus parasuis.China Animal Husbandry and Veterinary Medicine, 37 (12) : 173-176.

6. Li J, Xie Y Z, Xuan Xiongbiao, et al. (2011). Real time fluorescence PCR of Haemophilus parasuis Establishment and application of rapid detection method. Anhui Agricultural Sciences, 39(6) : 3607-3609.

7. Liang Q, Yang B, Yong S L, et al. (2018). PCR method for detection of Haemophilus parasuis. Modern Animal Husbandry and Veterinary Medicine, 358 (09) : 10-13. (in Chinese)

8. Lin, Wei-Hao, Shih, Hsing-Chun, Lin, Chuen-Fu, Yang, Cheng-Yao, Lin, Chao-Nan \& Chiou, Ming-Tang. (2019). Genotypic analyses and virulence characterization of Glaesserella parasuis isolates from Taiwan. PeerJ. 7. e6960. 10.7717/peerj.6960.

9. Ma, Lina, Wang, Liyan, Chu, Yuefeng, Li, Xuerui, Cui, Yujun, Chen, Shengli, Zhou, Jianhua, Li, Chunling, Lu, Zhongxin, Liu, Jixing \& Liu, Yongsheng. (2016). Characterization of Chinese Haemophilus parasuis Isolates by Traditional Serotyping and Molecular Serotyping Methods. PLoS ONE. 11. 10.1371/journal.pone.0168903.

10. Malorny B, Tassios P T, Radstrom P, et al. (2003). Standardization of diagnostic PC R for the detection of foodborne pathogens. Int J Food Microbiol, 83(1) : 39-48.

11. Moriy, Nagamine K, Tomita N, et al. (2010). Development of multiplex - PC R for identification of Pasteurella multocida, Haemophilus parasuis and Actinbacillus pleuropneumoniae. Anim Feed Sci Tech, (Z2) : 25-27.

12. Nedbalcova, Katerina, Satran, P., Jaglic, Zoran, Ondriasova, R. \& Kucerova, Z. (2018). Haemophilus parasuis and Glässer's disease in pigs: a review. Veterinární Medicína. 51. 168-179. 10.17221/5537-VETMED.

13. Ni, Hong-Bo, Gong, Qing-Long, Zhao, Quan, Li, Xiao-Yue, Zhang, Xiao-Xuan. (2020). Prevalence of Haemophilus parasuis"Glaesserella parasuis" in pigs in China: A systematic review and meta-analysis. Preventive Veterinary Medicine. 182.105083. 10.1016/j.prevetmed.2020.105083.

14. Rebenko H. I. (2014). Etiolohiia ta epizootolohiia infektsiinykh khvorob respiratornoho traktu svynei (ohliad literatury) [Etiology and epizootology of infectious diseases of the respiratory tract of pigs (literature review)] Visnyk SNAU seriia «Vet med». [Bulletin of the SNAU series "Vet Med"], № 1 (34), 114-121.

15. Si Z S, Wang G Y. (2011). Research progress of hemophilus parasuis . China Animal Husbandry and Veterinary Medicine, 38 (06): 179-182. (in Chinese with English abstract)

16. Starkey, S.R. \& Donnelly, T.M.. (2012). Pasteurella multocida. Clinical Veterinary Advisor: Birds and Exotic Pets. 717 719. 10.1016/B978-1-4160-3969-3.00418-2.

17. Xue G C, Ren T. (2009). Epidemiology and pathogenic factors of Haemophilus parasuis. Chinese Journal of Animal Husbandry and Veterinary Medicine, 36 (05): 168-171. (in Chinese) 
18. Zhang Bin, Tang Chen, Liao Ming, et al. (2014). Update on the pathogenesis of Haemophilus parasuis infection and virulence factors. Vet Microbiology, 168(1): 1-7.

19. Zhang Y, Li J, Li W J, et al. (2017). PCR method for detection of Bacillus multicidal bars Chinese Journal of Veterinary Medicine, 51 (05) : 16-21. (in Chinese with English abstract)

20. Zhang Yuan, Wei Caiwen, Li Jian, et al. (2014). Application of multiplex PCR in capsular sequencing of Pasteurella multocida. Chinese Journal of Veterinary Science, 44 (12): 1286-1291.

Чжан Юй, студент, Хенаньський науково-технічний інститут (Китай) та Сумський національний аграрний універcumem (Україна)

Ребенко Галина, PhD, Сумський національний аграрний університет (Суми, Україна),

Ху Цзяньхе, профресор, Інститут науки і техніки Хенань (Хенань, Китай)

Чжан Шоупінг, PhD, Інститут науки і техніки Хенань (Хенань, Китай)

\section{Розробка ПЛР для одночасного виявлення Pasteurella multocida ma Haemophilus parasuis}

Pasteurella multocida ma Haemophilus parasuis, $є$ основними збудниками ресnіраторних захворювань свиней на колективних свинарських фрермах усіх країн з розвиненим свинарством. Збудники мають значний вплив на дихальні шляхи свиней та серйозно перешкоджають росту і розвитку, а відповідно, знижують продуктивність. Тому метод швидкого виявлення цих мікроорганізмів є запорукою успішної профрілактики та контролю інфрекцій.

Традиційні методи лабораторних досліджень для підтвердження попереднього діагнозу, поставленого на підставі аналізу даних анамнезу, клінічних симптомів, патологічних змін та епідеміологічних характеристик захворювання, включають бактеріологічні дослідження Pasteurella multocida ma Haemophilus parasuis, культуральну, біохімічну та імунологічну ідентифрікацію. Ці методи трудомісткі й не можуть задовільнити потреби у швидкій діагностииі, що ускладнює можливості профрілактики та контролю хвороб тварин. Pasteurella multocida ma Haemophilus parasuis обидві є збудниками синдрому респіраторних захворювань свиней (PRDC), і часто виступають у вигляді асоціаційованої інфрекції, тому необхідно встановити точний і швидкий метод ідентифрікації обох загальних збудників респіраторних хвороб у свиней. У цій роботі Pasteurella multocida ma Haemophilus parasuis використовувались як об'єкти дослідження для розробки подвійного методу ПЛР-детекції.

Основний зміст досліджень полягає в наступному: було досліджено компоненти та реагенти та відпрацьовано покроковий порядок постановки подвійної ПЛР для одночасного виявлення Pasteurella multocida ma Haemophilus parasuis, використовуючи специфічні для Pasteurella multocida and Haemophilus parasuis праймери, а також, регулюючи концентрацію праймерів та температуру відпалу.

Meтод швидкого виявлення Pasteurella multocida ma Haemophilus parasuis, описаний у цьому дослідженні, має високу специфрічність та чутливість і може реалізувати швидку та точну ідентифрікацію патогенних бактерій за відносно короткий проміжок часу, забезпечуючи нові технічні засоби для швидкого виявлення Pasteurella multocida ma Haemophilus parasuis у лабораторіï.

Ключові слова: Pasteurella multocida; Haemophilus parasuis; подвійна ПЛР-детекція 